\title{
PENGEMBANGAN BAHAN AJAR DESAIN GRAFIS COREL DRAW BERBASIS KECAKAPAN HIDUP (LIFE SKILLS) PADA LEMBAGA KURSUS DAN PELATIHAN (LKP)
}

\author{
Pahala BP Rajagukguk ${ }^{1}$, Abdul Muin Sibuea ${ }^{2}$,Julaga Situmorang ${ }^{3}$ \\ ${ }^{1}$ BP-Pendidikan Anak Usia Dini (PAUD) dan Dikmas Sumatera Utara \\ ${ }^{2,3}$ Pascasarjana Universitas Negeri Medan \\ pahalabranles@gmail.com ${ }^{l}$
}

\begin{abstract}
Abstrak: Penelitian ini bertujuan untuk menghasilkan Bahan Ajar Desain Grafis Corel Draw Berbasis Kecakapan Hidup, dan untuk mengetahui kelayakan dan keefektifan Bahan Ajar Desain Grafis Corel Draw Berbasis Kecakapan Hidup. Penelitian pengembangan dengan menggunakan pengembangan model Borg and Gall dan pengembangan bahan ajar merujuk pada Dick and Carey. Ujicoba dilakukan pada peserta didik LKP Central Com Kota Gunung Sitoli Nias. Hasil penelitian ini menunjukkan: (1) Uji ahli materi pelajaran desain grafis corel draw berada pada kriteriasangat baik dan layak, (2) Uji ahli media pembelajaran berada pada kriteria sangat baik dan layak, (3) Uji ahli desain pembelajaran berada pada kriteria sangat baik dan layak, (4) uji coba perorangan berada pada kriteria sangat baik, (5) Uji coba kelompok kecil berada pada kriteria sangat baik, (6) Uji coba lapangan berada pada kriteria sangat baik, (7) Bahan Ajar Desain Grafis Corel Draw Berbasis PKH pada LKP sangat efektif digunakan . Hal ini terlihat dari hasil penelitian, yaitu pada peserta didik yang dibelajarkan dengan menggunakan bahan ajar ini, ditemukan bahwa skor hasil belajar dari 26 responden diperoleh skor terkecil 65 dan skor tertinggi 90, nilai rata-rata 76,54 dan standar deviasi 5,96. Pada peserta didik yang dibelajarkan dengan tidak menggunakan Buku Ajar Desain Grafis Corel Draw Berbasis Kecakapan Hidup pada LKP, ditemukan bahwa skor hasil belajar dari 26 responden didapat skor terkecil 55 dan skor tertinggi 80, nilai rata-rara 67,89 dan standar deviasi 6,03. Dari hasil perhitungan dipeoleh thitung = 7,22 sedangkan ttabel $=2,01$. Karena thitung $=7,22>t$ table $=2,01$ sehingga ada perbedaan yang signifikan dalam presentasi antara peserta didik yang menggunakan Buku Ajar Desain Grafis Corel Draw Berbasis Kecakapan Hidup (PKH) pada lembaga kursus pelatihan dengan yang tidak menggunakan Buku Ajar Desain Grafis Corel Draw Berbasis Kecakapan Hidup pada LKP.
\end{abstract}

Kata Kunci: pengembangan bahan ajar, desain grafis corel draw, kecakapan hidup, lembaga kursus dan pelatihan

\begin{abstract}
This study aims to produce Corel Draw Graphic Design Teaching Material Based on Life Skills, and to determine the feasibility and effectiveness of Corel Draw Graphic Design Teaching Material Based on Life Skills. Development research using the Borg and Gall model development and development of teaching materials refers to Dick and Carey. The test was conducted on LKP Central Com students in Gunung Sitoli City, Nias. The results of this study indicate: (1) the expert test of corel draw graphic design subject matter is in very good and decent criteria, (2) the learning media expert test is in very good and feasible criteria, (3) the learning design expert test is in very good criteria and feasible, (4) individual trials are in very good criteria, (5) Small group trials are in very good criteria, (6) Field trials are in very good criteria, (7) Corel Draw Based Graphic Design Teaching Materials PKH on LKP is very effective to use. This is evident from the results of the study, namely in students who were taught using this teaching material, it was found that the learning outcomes score of 26 respondents obtained the smallest score of 65 and the highest score of 90, an average value of 76.54 and a standard deviation of 5.96. In students who were taught by not using Corel Draw Graphic Design Textbooks Based on Life Skills in LKP, it was found that the learning outcomes of 26 respondents obtained the smallest score of 55 and the highest score of 80 , the average score of 67.89 and the standard deviation of 6.03 . From the calculation results obtained thitung $=7.22$ while ttable $=2.01$. Because tcount $=7.22>t$ table $=2,01$, so there is a significant difference in presentation between students who use Corel Draw Based Design Skills in Life Skills (PKH) in training course institutions and those who do not use Corel Graphic Design Textbooks Life Skills Based Draw on LKP.
\end{abstract}

Keywords: development of teaching materials, corel draw graphic design, life skills, course institutions and training 


\section{PENDAHULUAN}

Tujuan pendidikan Nasional adalah untuk mengembangkan potensi peserta didik agar menjadi manusia yang beriman dan bertakwa kepada Tuhan yang maha Esa, berakhlak mulia, sehat, berilmu, cakap, kreatif, mandiri dan menjadi warga negara yang demokratis serta bertanggung jawab (Depdiknas, 2003). Untuk mencapai tujuan tersebut, pemerintah dan lembaga-lembaga yang bergerak dalam bidang pendidikan telah melakukan berbagai pembaharuan dan penyempurnaan yang dipngaruhi dengan perubahan perubahan dibidang sains dan teknologi berskala nasional maiupun global.

Proses pelaksanaan pendidikan dapat berlangsung dalam keluarga , masyarakat dan persekolahan. Dengan melalui proses pendidikan, diharapkan manusia dapat meningkatkan tarif hidupnya melalui usaha dan kerja keras sesuai dengan keterampilan yang dimilikinya. Pendidikan yang berkualitas akan memiliki sumberdaya manusia (SDM) yang hadai, dan sebaliknya pendidikan yang berlangsung haya mementingkan segi kuantitasnya saja, akan menjadi beban bagi pembagunan bangsa. (Thomas, 2002) mengatakan bahwa untuk mempersiapkan bangsa yang berkualitas diperlukan penyelenggaraan pendidikan yang berkualitas pula.

Pendidikan bila dikaitkan dengan pembahasan kecakapan hidup (life skills) difokuskan pada sekolah dan sistem persekolahan, berangkat dari universalisasi yang terus meluas dan meningkat. Kecakapan hidup, terutama kecakapan hidup sehari-hari (day to day life skills) semakin dirasakan pentingnya bagi kehidupan personal dan kolektif yang sering kali berhadapan dengan fenomena kehidupan dengan berbagai persoalan di tingkat pribadi, lokal, nasional, regional dan global (Sumarni, 2002). Sebagai modal dasar pembangunan bangsa dan pemerataan daya tampung pendidikan harus disertai pemerataan mutu pendidikan sehingga mampu dijangkau oleh seluruh lapisan masyarakat. Salah satu konsep yang sangat sentral dari program pendidikan kecakapan hidup adalah pendidikan diharapkan mampu untuk memecahkan masalah-masalah yang timbul karena itu pendidikan harus dapat mensinergikan berbagai pelajaran menjadi sebuah kecakapan atau ketrampilan hidup dengan harapan bahwa para lulusan itu nantinya akan mampu memecahkan masalah-masalah yang sedang dan akan ia hadapi. Salah satu di antaranya adalah dapat menciptakan suatu pekerjaan. Konsep dasar life skills di sekolah merupakan sebuah wacana pembangunan kurikulum yang telah lama menjadi perhatian para pakar kurikulum. Peran life skills dalam sistem sekolah merupakan salah satu fokus analisis dalam pengembangan kurikulum pendidikan yaitu yang lebih menekankan pada kecakapan hidup atau bekerja untuk mewujudkannya perlu penerapan prinsip pendidikan berbasis luas, yang memiliki titik tekan pada "learning how to learn".

Desain grafis adalah sebuah program kursus yang bersifat vokasional atau keterampilan hidup di lembaga kursus dan pelatihan (LKP). Berbagai upaya telah dilakukan untuk meningkatkan kualitas pembelajaran desain grafis di LKP baik oleh pemerintah maupun oleh LKP itu sendiri. Menurut (Situmorang, 2012) upaya pengembangan kualitas pembelajaran sudah dilakukan di LKP, yaitu pengembangan kurikulum, yaitu sillabus, rencana pelaksanaan pembelajaran (RPP), jadwal pelaksanaan latihan, strategi pelatihan, bahan ajar dan evaluasi pembelajaran, tetapi belum mampu untuk meningkatkan kualitas pengajaran di LKP. Di antara komponen kurikulum tersebut salahsatu yang terpenting adalah perlu dikembangkan bahan ajar yang mampu memberikan efektifitas dalam pembelajaran.

Bahan ajar yaitu segala bentuk bahan yang digunakan untuk membantu guru / instruktur dalam melaksanakan kegiatan belajar mengajar di kelas (Amri dan Ahmadi, 2010). Bahan ajar tersebut bisa berupa bahan tertulis dan bahan tidak tertulis. Buku ajar adalah salah satu bentuk dari bahan ajar tertulis. Menurut Sitepu (2005) buku ajar merupakan suatu sumber ajar dan pembelajaran yang memberiakn andil cukup besar dalam upaya memperluas kesempatan memperoleh pendidikan sekaligus juga meningkatkan mutu proses dan hasil pembelajaran. Pembelajaran sains juga membutuhkan dua hal penting mrupakan sumber utama pengetahuan sains dalam kelas - kelas sains (Imbi dan Pritt, 2010). Berdasarkan peran dan fungsi bahan ajar diatas dapat disimpulkan bahwaajar merupakan media untuk memfasilitasi siswa dalam melakukan kegiatan pembelajaran yang dapat meningkatkan hasil belajar siswa. 
Dalam hal ini Plomp dan Ely (1996) menjelaskan bahwa karakreristik yang perlu diperhatikan dalam merancang buku ajar adalah ; (a) isi pesanannya harus dianalisis dan diklasifikasi ke dalam kategori - kategori tertentu,(b) setiap kategori haru dipenggal menjadi beberapa penggalan teks, (c) perlu ada penyajian format visualisasi untuk memberikan kemenarikan isi content appealing) (d) ktegori dalam kajian penelitian ini, desain pengembangan buku ajar dilakukan melalui medel analisis tugas belajar. Model analisis tugas belajar diperolehurutan yang logis dan sistematis, artiya guru mengarkan meteri ajar secara hirarki dan saling berhubungan. Pengorganisasian isis materi buku ajar melalui model analisis tugas akan mengarahkan siswa kapada upaya penguasaan keterampilan dan menemukan sendiri cara belajarnya.

\section{Hakikat Buku Ajar Sebagai Media Cetak}

Peraturan Menteri Pendidikan Nasional

No. 11 Tahun 2005 menjelaskan bahwa buku ajar adalah buku acuan wajib untuk digunakan di sekolah yang memuat meteri pambelajaran dalam rangka peningkatan keimanan dan kekwaan, budi pekerti dan kepribadian, kemampuan penguasaan ilmu pengetahuan dan teknologi, kepekaan dan kemampuan estetis, serta potensi fisik dan kesahatan yang disusun berdasarkan standart Nasional Pendidikan. Menurut (Trianto, 2011:227), buku ajar (modul, diktat ) merupakan buku panduan bagi siswa dalam kegiatan pembelajaran konsep, kegiatan sains, informasi dan contoh-contoh penerapan sains informasi dan contoh-contoh penerapan sains, dalam kehidupan sehari - hari. Menurut (Muclich, 2010) mendefinisikan buku ajar sebagai buku yang berisi uraian bahan tenteng mata pelajaran atau bidang studi tertentu, yang disusun secara sistematis dan telah diseleksi berdasarkan tujuan tertentu, orientasi pembelajaran dan perkembangan siswa untuk di asimilasikan. Menurut (Sofan \& Iif, 2010 : 59) mendefinisikan buku ajar sebagai segala bentuk bahan yang digunakan untuk membantu guru/ instruktur dalam melaksanakan kegiatan belajar mengajar di kelas. Bahan atau meteri pelajaran (learning meterials) adalah segala sesuatu yang menjadi isi kurikulum yang harus dikuasai oleh siswa sesuai dengan kompetensi dasar dalam satuan pendidikan tertentu (Sanjaya , 2010 : 141).

\section{Pengertian Desain Grafis}

Desain adalah merencanakan atau designing artinya membuat pola-pola. Arti keseluruhan dari desain adalah proses merencanakan suatu karya seni yang terpakai, dengan mengindahkan fungsi, komposisi warna, tata letak, bentuk, harga dan bisa diproduksi banyak, keinginan pasar serta bisa laku dijual. (Taufiq, 2009:1).

\section{Pengertian dan konsep Kecakapan Hidup}

Kecakapan Hidup (life skills) diartikan sebagai kecakapan yang dimiliki seseorang untuk mau dan berani menghadapi hidup dan penghidupan secara wajar tanpa merasa tertekan, kemudian secara proaktif dan kreatif mencari serta menemukan solusi sehingga akhirnya mampu mengatasinya (Dirjen PLSP, Direktorat Teknis, 2003).

Menurut Brolin 1989 dalam bukunya Anwar yang berjudul Pendidikan Kecakapan Hidup Konsep dan Aplikasinya menjelaskan bahwa: "life skills constitute a continuum of knowledge and aptitude that are necessary for a person to function efectively and to avoid interruption of employment experience".

Kecakapan hidup merupakan sebuah rangkaian kesatuan tentang sebuah pengetahuan dan itu merupakan kebutuhan seseorang untuk tujuan yang efektif dalam memecahkan masalah dari sebuah pengalaman. Dengan demikian life skills dapat dinyatakan sebagai kecakapan untuk hidup.

Menurut (Departemen pendidikan Nasional, 2003) pendidikan kecakapan hidup menjadi empat jenis, yaitu:

a. Kecakapan personal (personal skills) yang mencakup kecakapan mengenal diri (self awareness) dan kecakapan berfikir rasional (thinking skills)

b. Kecakapan sosial (social skills)

c. Kecakapan akademik (academic skills)

d. Kecakapan vocational (vocational skills)

Kemampuan dasar dalam pendidikan kecakapan hidup sebagai mana telah disampaikan di atas, atau indikator-indikator yang terkandung dalam life skills tersebut secara konseptual dikelompokkan sebagai berikut : 1) kecakapan mengenal diri (self awarness) atau sering juga disebut kemampuan personal (personal skills), 2) kecakapan berpikir rasional (thinking skills) atau kecakapan akademik (academic skills), 3) kecakapan sosial (social skills), dan 4) kecakapan vokasional (vocational skills) sering juga disebut dengan 
keterampilan kejuruan artinya keterampilan yang dikaitkan dengan bidang pekerjaan tertentu dan bersifat spesifik (spesifict skills) dan teknikal skills (technical skills).

\section{Bahan Ajar Desain Grafis Berbasis Kecakapan Hidup}

Bahan ajar desain grafis berbasis kecakapan hidup adalah bahan ajar yang dirancang untuk memberikan pembelajaran yang mampu mengembangkan potensi peserta didik untuk memiliki ketrampilan, pengetahuan, dan sikap bidang desain grafis sebagai bekal hidupnya agar dapat digunakan untuk mencari nafkah dan bermasyarakat. Bahan ajar desain grafis berbasis kecakapan hidup mampu mengembangkan potensi peserta didik atau kecakapan hidup peserta didik yaitu : 1) kecakapan mengenal diri (self awarness) atau sering juga disebut kemampuan personal (personal skills), 2) kecakapan berpikir rasional (thinking skills) atau kecakapan akademik (academic skills), 3) kecakapan sosial (social skills), dan 4) kecakapan vokasional (vocational skills) sering juga disebut dengan keterampilan kejuruan artinya keterampilan yang dikaitkan dengan bidang pekerjaan tertentu dan bersifat spesifik (spesifict skills) dan teknikal skills (technical skills).

Berdasarkan latar belakang, identifikasi masalah, dan batasan masalah, maka permasalahan masalah yang dikaji pada penelitian ini sebagai berikut: (1) Bagaimana Pengembangan bahan ajar desain grafis corel draw berbasis kecakapan hidup pada LKP Central Com?; (2) Bagaimana implementasi bahan ajar desain grafis corel draw berbasis kecakapan hidup pada LKP Central Com?; dan (3) Apakah ada perbedaan efetivitas bahan ajar yang dikembangkan dengan bahan ajar yang digunakan pada desain grafis corel draw untuk program kursus LKP Central Com

\section{METODE}

Penelitian ini dilakukan di LKP Central Com Kota Gunung Sitoli Nias yang beralamat J1.Diponegoro No. 186-A Kota Gunung Sitoli Nias. Pengembangan bahan ajar ini dilakukan dengan menggunakan model pengembangan Borg dan Gall (1983) yang dipadu dengan model desain pembelajaran Dick \& Carey. Sehingga langkah-lagkah pengembangan Bahan ajar ini adalah sebagai berikut: (1) melakukan penelitian pendahuluan, yang meliputi : (a) identifikasi kebutuhan atau tujuan pembelajaran dan menentukan standart kompetensi mata pelajaran, (b) melakukan analisis pembelajaran dengan menentukan keterampilan yang lebih khusus yang harus dipelajari, (c) mengidentifikasi karakteristik dan perilaku awal peserta didik, dan (d) menulis kompetensi dasar dan indikatornya; (2) menyusun tes acuan patokan dengan mengembangkan butir penilaian untuk mengukur kemampuan peserta didik yang diperkirakan di dalam tujuan pembelajaran; (3) pengumpulan bahan, yaitu meliputi : (a) pengumpulan materi pembelajaran, (b) pembuatan dan pengumpulan Gambar (ilustrasi); (4) pengembangan produk (Bahan ajar); (5) validasi produk; (6) revisi produk; dan (7) ujicoba produk.

\section{Prosedur Pengembangan}

Prosedur pengembangan Bahan ajar Desain Grafis Corel Draw Berbasis Pendidikan KecakapanHidup pada lembaga kursus dan pelatihan ini adalah sebagai berikut :

a. Analisis masalah dan kebutuhan dilakukan untuk mengumpulkan informasi (kajian pustaka, analisis standar kompetensi (SK) dan kompetensi dasar (KD), dan pengamatan terhadap buku teks yang digunakan di LKP Central Com Kota Gunung Sitoli Nias.

b. Perencanaan produk/Bahan ajar berbasis keckapan hidup pada lembaga kursus dan pelatihan.

c. Menyusun Bahan ajar berbasis kecakapan hidup pada lembaga kursus dan pelatihan.

d. Menyusun instrumen uju coba, yaitu lembar angket penilaian bagi validator.

e. Revisi ahli materi dilakukan dengan menggunakan lembar validasi kelayakan materi Bahan ajar.

f. Revisi pertama yang dilakukan merupakan hasil analisis, masukan, dan saran-saran ddari hasil penilaian ahli materi pembelajaran.

g. Reviu ahli desain pembelajaran dengan menggunakan lembar validasi kelayakan desain Bahan ajar.

h. Revisi kedua dilakukan terhadap produk dari hasil penilaian ahli desain pembelajaran.

i. Reviu ahli media pembelajaran dengan menggunakan lembar validasi kelayakan media yang dikembangkan.

j. Ujicoba perorangan yang dilakukan 
terhadap tiga orang siswa, dan pengumpulan data/informasi dilakukan dengan menggunakan angket (kuesioner).

k. Revisi ketiga terhadap produk dari hasil ujicoba perorangan jika dibutuhkan revisi.

1. Ujicoba kelompok kecil yang dilakukan terhadap sembilan orang peserta didik. Pengumpulan data dilakukan dengan menggunakan angket (kuesioner).

m. Revisi keempat terhadap produk dari hasil ujicoba kelompok kecil jika dibutuhkan revisi.

n. Ujicoba kelompok lapangan terbatas yang dilakukan terhadap lima puluh dua orang peserta didik di LKP Central Com Kota Gunung Sitoli Nias. Pengumpulan data dilakukan dengan menggunakan angket (kuesioner).

o. Data dianalisis, diolah, dan ditarik kesimpulan dari hasil penelitian.

p. Hasil akhir merupakan produk Bahan ajar berupa buku dari hasil revisi keempat yang siap diterapkan pada pembelajaran untuk dilihat efektivitasnya.

Data yang diperoleh adalah data tentang bahan ajar yang dikembangkan. Data ini adalah data yang dikumpulkan melalui validasi pakar, kuesioner/angket yang disebarkan kepada peserta didik. Instrumen penelitian untuk validator dan ujicoba perorangan, kelompok kecil, maupun ujicoba kelompok lapangan terbatas, dibuat dalam bentuk Skala Likert yang telah diberikan skor seperti terlihat pada Tabel 1 .

Tabel 1 Kriteria Jawaban Item Instrumen Validasi dengan Jenis Skala Likert Beserta Skornya.

\begin{tabular}{|c|c|c|}
\hline No. & Jawaban & Skor \\
\hline 1. & Sangat baik & 4 \\
\hline 2. & Baik & 3 \\
\hline 3. & Kurang baik & 2 \\
\hline 4. & Tidak baik & 1 \\
\hline
\end{tabular}

(Sugiyono; 2011)

Kemudian data dianalisis secara deskriptif kuantitatif, yaitu menghitung persentase indikator untuk setiap kategori pada Bahan ajar yang dikembangkan.

persentase skor $=\frac{\text { jumlahidikatorperkategori }}{\text { jumlahtotalindikatorkategori }} \times 100 \%$

Dari hasil perhitungan dengan menggunakan rumus di atas, dihasilkan angka dalam bentuk persen (\%). Klasifikasi skor tersebut selanjunya diubah menjadi klasifikasi dalam bentuk persentase (Sugiyono ; 2000), kemudian ditafsirkan dengan kualitatif yang tercantum Tabel 2.

Tabel 2 Kriteria Jawaban Item Instrumen Validasi dengan Jenis Skala Likert Beserta persentase Skornya.

\begin{tabular}{|c|c|c|}
\hline No. & Kriteria & Persentase (\%) \\
\hline 1. & Sangat baik & $80 \% \leq \mathrm{x} \leq 100 \%$ \\
\hline 2. & Baik & $60 \% \leq \mathrm{x}<80 \%$ \\
\hline 3. & Kurang baik & $40 \% \leq \mathrm{x}<60 \%$ \\
\hline 4. & Tidak baik & $0 \% \leq \mathrm{x}<40 \%$ \\
\hline
\end{tabular}

(Sugiyono; 2000)

\section{Uji Efektivitas Produk}

Penelitian ini dilakukan di LKP Central Com Kota Gunung Sitoli Nias yang dilaksanakan bulan Juni sampai dengan bulan Juli tahun 2016.

\section{Populasi dan Sampel Penelitian}

a) Populasi

Populasi dalam penelitian ini adalah semua peserta didik program kursus Desain Grafis yang sedang belajar atau mengambil program kursus Desain Grafis di semua LKP Central Com.

b) Sampel Penelitian

Sampel penelitian adalah semua peserta didik program krsus desain grafis corel draw di LKP Central Com Kota Gunung Sitoli Nias.

\section{Rancangan Eksperimen}

Penelitian ini melibatkan dua kelas, yaitu kelas eksperimendan kelas kontrol, dimana kedua kelas ini diberi tes sebanyak dua kali yaitu pre-test dan post-test.

Pelaksanaan penelitian ini dilaksanakan dengan langkah-langkah sebagai berikut :

1) Tahap persiapan : berkoordinasi dan mengkomfirmasi LKP Central Com tentang penelitian ini, kemudian menyusun jadwal penelitian, menyusun rencana pembelajran, pre tes, perlakuan, dan post tes.

2) Thap Pelaksanaan: penelitian dilaksanakan pada tahun ajaran 2016 dengan sampel terdiri dari dua kelas, yaitu kelas dengan pelaksanaan kegiatan belajar mengajar menggunakan bahan ajar yang dikembangkan dan kelas kontrol tidak 
menggunakan bahan ajar yang dikembangkan atau menggunakan bahan ajar biasa.

Teknik analisa data yang digunakan pada penelitian ini adalah teknik analisis kuantitatif. Untuk mengetahui perbedaan yang signifikan antara hasil belajar dengan penggunaan Bahan ajar dan buku teks dilakukan dengan menggunakan uji beda (uji-t) (Sudjana, 1989) yaitu :

$$
t=\frac{\overline{X_{1}}+\overline{X_{2}}}{s \sqrt{\frac{1}{n_{1}}+\frac{1}{n_{n}}}},
$$

dimana $S$ adalah varians gabungan yang dihitung dengan rumus :

$$
S^{2}=\frac{\left(n_{1}-1\right) S_{1}^{3}+\left(n_{2}-1\right) S_{2}^{a}}{n_{1}+n_{2}-2}
$$

Dimana :

$t=$ Distribusi $\mathrm{t}$

$\mathrm{x}_{1}=$ rata-rata peserta didik menggunakan Bahan ajar

$\mathrm{x}_{2}=$ rata-rata peserta didik yang menggunakan buku teks $n_{l}=$ jumlah peserta didik yang menggunakan Bahan ajar

$n_{2}=$ jumlah peserta didik yang menggunakan buku teks

$S=$ varians gabungan

$S_{l}=$ simpangan baku peserta didik yang menggunakan Bahan ajar

$S_{2}=$ simpangan baku peserta didik yang menggunakan buku teks

Dengan $d k=\left(n_{1}+n_{2}-2\right)$, kriteria korelasi yang diperoleh dikatakan signifikan (hipotesis diterima) jika harga $t_{\text {hitung }}>$ $t_{\text {Tabel }}$ untuk taraf signfikasi 0,05. Untuk melihat keefektifan Bahan ajar yang dieksperimenkan digunakan rumus perhitungan efektifitas berikut (sugiyono, 2011) :

$$
=\frac{\text { jumlahskoryangdiperoleh }}{\text { jumlahskoridealseluruhitem }} \times 100 \%
$$

\section{HASIL DAN PEMBAHASAN \\ Hasil Uji Tahap I Uji Coba Perorangan}

\begin{tabular}{|c|c|c|c|c|c|c|c|}
\hline \multirow{2}{*}{ Aspek } & \multirow{2}{*}{ Diskripsi } & \multicolumn{3}{|c|}{ Reviewer } & \multirow{2}{*}{$\begin{array}{l}\text { Jlh } \\
\text { Skor }\end{array}$} & \multirow{2}{*}{$\begin{array}{l}\text { Rata- } \\
\text { rata }\end{array}$} & \multirow{2}{*}{ Persentase } \\
\hline & & 1 & 2 & 3 & & & \\
\hline \multirow{4}{*}{$\begin{array}{l}\text { Kelayak } \\
\text { an isi }\end{array}$} & $\begin{array}{l}\text { Cakupan materi yang ada dalam buku } \\
\text { ajar jelas dan runtut sehingga mudah } \\
\text { saya pahami }\end{array}$ & 3 & 3 & 3 & 3 & 3 & $75 \%$ \\
\hline & $\begin{array}{l}\text { Masalah yang disajikan dalam materi } \\
\text { buku ajar, sesuai dengan kehidupan } \\
\text { sehari-hari saya }\end{array}$ & 3 & 3 & 4 & 10 & 3,33 & $83,33 \%$ \\
\hline & $\begin{array}{l}\text { Saya merasa senang jika pelajaran } \\
\text { menggunakan buku ajar ini }\end{array}$ & 3 & 4 & 3 & 10 & 3,33 & $83,33 \%$ \\
\hline & $\begin{array}{l}\text { Penggunaan buku ajar dalam } \\
\text { kegiatan pembelajaran akan lebih } \\
\text { mudah untuk saya pahami }\end{array}$ & 3 & 3 & 3 & 9 & 3 & $75 \%$ \\
\hline \multicolumn{5}{|c|}{ Jumlah Skor } & 38 & 12,66 & $\begin{array}{l}\text { Rerata }= \\
79,16 \%\end{array}$ \\
\hline \multirow{5}{*}{$\begin{array}{l}\text { Kelayak } \\
\text { an } \\
\text { penyaji } \\
\text { an }\end{array}$} & $\begin{array}{l}\text { Penyajian buku ajar membuatasaya } \\
\text { tertarik untuk membacanya }\end{array}$ & 4 & 3 & 4 & 11 & 3,66 & $91,67 \%$ \\
\hline & $\begin{array}{l}\text { Buku ajar dilengkapi dengan Gambar } \\
\text { dan Tabel yang jelas }\end{array}$ & 3 & 4 & 4 & 11 & 3,66 & $91,67 \%$ \\
\hline & $\begin{array}{l}\text { Buku ajar dilengkapi dengan } \\
\text { rangkuman materi yang mencakup } \\
\text { seluruh isi materi }\end{array}$ & 4 & 4 & 3 & 11 & 3,66 & $83,33 \%$ \\
\hline & $\begin{array}{l}\text { Buku ajar dilengkapi dengan } \\
\text { glossarium }\end{array}$ & 3 & 4 & 3 & 10 & 3,33 & $91,67 \%$ \\
\hline & $\begin{array}{l}\text { Buku ajar dilengkapi dengan daftar } \\
\text { pustaka yang jelas }\end{array}$ & 4 & 4 & 3 & 11 & 3,66 & $91,67 \%$ \\
\hline \multicolumn{5}{|c|}{ Jumlah Skor } & 54 & 17,97 & $\begin{array}{l}\text { Rerata }= \\
90 \%\end{array}$ \\
\hline
\end{tabular}
pada Tabel 3.

Tabel 3. Hasil Angket Uji Coba Perorangan 


\begin{tabular}{|c|l|c|c|c|c|c|c|}
\hline $\begin{array}{c}\text { Kelayak } \\
\text { an } \\
\text { Bahasa }\end{array}$ & $\begin{array}{l}\text { Bahasa yang digunakan dalam buku } \\
\text { ajar sesuai dengan EYD }\end{array}$ & 3 & 3 & 4 & 10 & 3,33 & $83,33 \%$ \\
\cline { 2 - 7 } & $\begin{array}{l}\text { Bahasa yang digunakan dalam buku } \\
\text { ajar komunikatif dan mudah saya } \\
\text { pahami }\end{array}$ & 4 & 3 & 3 & 10 & 3,33 & $83,33 \%$ \\
\cline { 2 - 7 } & $\begin{array}{l}\text { Struktur kalimat yang digunakan } \\
\text { dalam buku ajar jelas dan sederhana }\end{array}$ & 3 & 4 & 4 & 11 & 3,66 & $91,67 \%$ \\
\hline \multicolumn{6}{|c|}{ Jumlah Skor } \\
\hline \multicolumn{7}{|c|}{ Persentase Skor Total } \\
\hline
\end{tabular}

\section{Data Hasil Uji Tahap II Uji Coba Kelompok Kecil}

Uji coba kelompok kecil ini digunakan sebagai pengalaman awal sebelum produk diujicobakan ke lapangan.

Tabel 4. Data Hasil Angket Uji Coba Kelompok Kecil

\begin{tabular}{|c|c|c|c|c|c|c|c|c|}
\hline \multirow{2}{*}{ Aspek } & \multirow{2}{*}{ Diskripsi } & \multicolumn{4}{|c|}{ Skor } & \multirow{2}{*}{$\begin{array}{l}\text { Jlh } \\
\text { Skor }\end{array}$} & \multirow{2}{*}{$\begin{array}{c}\text { Rata- } \\
\text { rata }\end{array}$} & \multirow{2}{*}{ Persentase } \\
\hline & & 4 & 3 & 2 & 1 & & & \\
\hline \multirow{4}{*}{$\begin{array}{l}\text { Kelayakan } \\
\text { isi }\end{array}$} & $\begin{array}{l}\text { Cakupan materi yang ada } \\
\text { dalam buku ajar jelas dan } \\
\text { runtut sehingga mudah saya } \\
\text { pahami }\end{array}$ & 9 & - & - & - & 36 & 4 & $100 \%$ \\
\hline & $\begin{array}{l}\text { Masalah yang disajikan dalam } \\
\text { materi buku ajar, sesuai } \\
\text { dengan kehidupan sehari-hari } \\
\text { saya }\end{array}$ & 9 & - & - & - & 36 & 4 & $100 \%$ \\
\hline & $\begin{array}{l}\text { Saya merasa senang jika } \\
\text { pelajaran menggunakan buku } \\
\text { ajar ini }\end{array}$ & 1 & 8 & - & - & 25 & 2,6 & $69,44 \%$ \\
\hline & $\begin{array}{l}\text { Penggunaan buku ajar dalam } \\
\text { kegiatan pembelajaran akan } \\
\text { lebih mudah untuk saya } \\
\text { pahami }\end{array}$ & 2 & 7 & - & - & 27 & 3 & $75 \%$ \\
\hline \multicolumn{6}{|c|}{ Jumlah Skor } & 124 & 13,6 & $\begin{array}{l}\text { Rerata= } \\
\mathbf{8 6 , 1 1 \%}\end{array}$ \\
\hline \multirow{5}{*}{$\begin{array}{l}\text { Kelayakan } \\
\text { penyajian }\end{array}$} & $\begin{array}{l}\text { Penyajian buku ajar } \\
\text { membuatasaya tertarik untuk } \\
\text { membacanya }\end{array}$ & 7 & 2 & - & - & 34 & 3,7 & $94,44 \%$ \\
\hline & $\begin{array}{l}\text { Buku ajar dilengkapi dengan } \\
\text { Gambar dan Tabel yang jelas }\end{array}$ & 7 & 2 & - & - & 34 & 3,7 & $94,44 \%$ \\
\hline & $\begin{array}{l}\text { Buku ajar dilengkapi dengan } \\
\text { rangkuman materi yang } \\
\text { mencakup seluruh isi materi }\end{array}$ & 9 & - & - & - & 36 & 4 & $100 \%$ \\
\hline & $\begin{array}{l}\text { Buku ajar dilengkapi dengan } \\
\text { glossarium }\end{array}$ & 9 & - & - & - & 36 & 4 & $100 \%$ \\
\hline & $\begin{array}{l}\text { Buku ajar dilengkapi dengan } \\
\text { daftar pustaka yang jelas }\end{array}$ & 9 & - & - & - & 36 & 4 & $100 \%$ \\
\hline \multicolumn{6}{|c|}{ Jumlah Skor } & 176 & 19,55 & $\begin{array}{l}\text { Rerata= } \\
\mathbf{9 7 , 7 8 \%}\end{array}$ \\
\hline \multirow{3}{*}{$\begin{array}{l}\text { Kelayakan } \\
\text { Bahasa }\end{array}$} & $\begin{array}{l}\text { Bahasa yang digunakan dalam } \\
\text { buku ajar sesuai dengan EYD }\end{array}$ & 9 & - & - & - & 36 & 4 & $100 \%$ \\
\hline & $\begin{array}{l}\text { Bahasa yang digunakan dalam } \\
\text { buku ajar komunikatif dan } \\
\text { mudah saya pahami }\end{array}$ & 5 & 4 & - & - & 32 & 3,5 & $88,89 \%$ \\
\hline & Struktur kalimat yang & & & & & & & \\
\hline
\end{tabular}




\begin{tabular}{|l|l|l|l|l|l|l|l|l|}
\hline & $\begin{array}{l}\text { digunakan dalam buku ajar } \\
\text { jelas dan sederhana }\end{array}$ & 5 & 4 & - & - & 32 & 3,5 & $88,89 \%$ \\
\hline \\
Jumlah Skor \\
\hline \\
Persentase Skor Total \\
\hline
\end{tabular}

Tabel 5. Ikhtiar Data Hasil Kajian pada Uji Coba Kelompok kecil

\begin{tabular}{|l|l|}
\hline \multicolumn{1}{|c|}{ Topik } & \multicolumn{1}{c|}{ Masalah yang perlu direvisi } \\
\hline Contoh soal & $\begin{array}{l}\text { Perlu ditambahkan beberapa contoh soal agar dalam perjalanan latihan } \\
\text { dapat lebih baik lagi }\end{array}$ \\
\hline Soal latihan & Soal latihan dirasa cukup sulit untuk diselesaikan \\
\hline Praktik & $\begin{array}{l}\text { Perlu ditambahkan beberapa praktik dasar yang mudah dipahami dalam } \\
\text { buku ajar agar peserta didik lebih bersemangat untuk belajar }\end{array}$ \\
\hline
\end{tabular}

\section{Data Hasil Uji Coba Lapangan}

Uji coba lapangan menghasilkan data-data yang nantinya akan mengukur kelayakan dari produk yang dikembangkan, serta untuk mengetahui manfaat produk tersebut bagi pemakainya. Hasil evaluasi uji coba lapangan dapat dilihat pada Tabel 6.

Tabel 6. Data Hasil Angket Uji Coba Lapangan

\begin{tabular}{|c|c|c|c|c|c|c|c|c|}
\hline \multirow{3}{*}{ Aspek } & \multirow{3}{*}{ Diskripsi } & \multicolumn{4}{|c|}{ Skor } & \multirow{3}{*}{$\begin{array}{l}\text { Jlh } \\
\text { Skor }\end{array}$} & \multirow{3}{*}{$\begin{array}{l}\text { Rata- } \\
\text { rata }\end{array}$} & \multirow{3}{*}{$\begin{array}{l}\text { Persentas } \\
\text { e Skor } \\
\text { Ideal }\end{array}$} \\
\hline & & & & & & & & \\
\hline & & 4 & 3 & 2 & 1 & & & \\
\hline \multirow{4}{*}{$\begin{array}{l}\text { Kelayakan } \\
\text { isi }\end{array}$} & $\begin{array}{l}\text { Cakupan materi yang } \\
\text { ada dalam buku ajar } \\
\text { jelas dan runtut } \\
\text { sehingga mudah saya } \\
\text { pahami }\end{array}$ & 16 & 18 & - & - & 118 & $3,47 \%$ & $86,76 \%$ \\
\hline & $\begin{array}{l}\text { Masalah yang } \\
\text { disajikan dalam } \\
\text { materi buku ajar, } \\
\text { sesuai dengan } \\
\text { kehidupan sehari-hari } \\
\text { saya }\end{array}$ & 18 & 15 & 1 & - & 117 & 3,44 & $86,02 \%$ \\
\hline & $\begin{array}{l}\text { Saya merasa senang } \\
\text { jika pelajaran } \\
\text { menggunakan buku } \\
\text { ajar ini }\end{array}$ & 11 & 23 & - & - & 113 & 3,33 & $83,08 \%$ \\
\hline & $\begin{array}{l}\text { Penggunaan buku ajar } \\
\text { dalam kegiatan } \\
\text { pembelajaran akan } \\
\text { lebih mudah untuk } \\
\text { saya pahami }\end{array}$ & 17 & 17 & - & - & 119 & 3,5 & $87,5 \%$ \\
\hline \multicolumn{6}{|c|}{ Jumlah Skor } & 467 & 13,74 & $\begin{array}{l}\text { Rerata= } \\
85,84 \%\end{array}$ \\
\hline \multirow{3}{*}{$\begin{array}{c}\text { Kelayakan } \\
\text { penyajian }\end{array}$} & $\begin{array}{l}\text { Penyajian buku ajar } \\
\text { membuatsaya tertarik } \\
\text { untuk membacanya }\end{array}$ & 16 & 18 & - & - & 118 & 3,47 & $86.76 \%$ \\
\hline & $\begin{array}{l}\text { Buku ajar dilengkapi } \\
\text { dengan Gambar dan } \\
\text { Tabel yang jelas }\end{array}$ & 26 & 8 & - & - & 128 & 3,76 & $94,12 \%$ \\
\hline & $\begin{array}{l}\text { Buku ajar dilengkapi } \\
\text { dengan rangkuman } \\
\text { materi yang }\end{array}$ & 19 & 14 & 1 & - & 120 & 3,53 & $88,23 \%$ \\
\hline
\end{tabular}




\begin{tabular}{|c|c|c|c|c|c|c|c|c|}
\hline & $\begin{array}{l}\text { mencakup seluruh isi } \\
\text { materi }\end{array}$ & & & & & & & \\
\hline & $\begin{array}{l}\text { Buku ajar dilengkapi } \\
\text { dengan glossarium }\end{array}$ & 26 & 8 & - & - & 128 & $3,76 \%$ & $100 \%$ \\
\hline & $\begin{array}{l}\text { Buku ajar dilengkapi } \\
\text { dengan daftar pustaka } \\
\text { yang jelas }\end{array}$ & 30 & 4 & - & - & 132 & 3,88 & $97,06 \%$ \\
\hline \multicolumn{6}{|c|}{ Jumlah Skor } & 626 & 18,4 & $\begin{array}{l}\text { Rerata= } \\
\text { 92,06\% }\end{array}$ \\
\hline \multirow{3}{*}{$\begin{array}{c}\text { Kelayakan } \\
\text { Bahasa }\end{array}$} & $\begin{array}{lr}\text { Bahasa } & \text { yang } \\
\text { digunakan } & \text { dalam } \\
\text { buku ajar } & \text { sesuai } \\
\text { dengan EYD } & \end{array}$ & 14 & 9 & 1 & - & 115 & 3,38 & $84,56 \%$ \\
\hline & $\begin{array}{lr}\text { Bahasa } & \text { yang } \\
\text { digunakan dalam } \\
\text { buku ajar komunikatif } \\
\text { dan mudah saya } \\
\text { pahami }\end{array}$ & 15 & 19 & - & - & 117 & 3,44 & $86,02 \%$ \\
\hline & $\begin{array}{l}\text { Struktur kalimat yang } \\
\text { digunakan dalam } \\
\text { buku ajar jelas dan } \\
\text { sederhana }\end{array}$ & 16 & 18 & - & - & 118 & 3,47 & $86,76 \%$ \\
\hline \multicolumn{6}{|c|}{ Jumlah Skor } & 350 & 10,29 & $\begin{array}{l}\text { Rerata }= \\
\mathbf{8 5 , 7 8 \%}\end{array}$ \\
\hline \multicolumn{8}{|c|}{ Persentase Skor Total } & $87,89 \%$ \\
\hline
\end{tabular}

\section{Analisis Data Hasil Evaluasi Ahli Materi}

Data hasil angket uji coba lapangan Buku Ajar Desain Grafis Corel Draw berbasis kecakapan hidup seperti yang disajikan pada Tabel 7.

Tabel 7. Skor rata-rata Hasil Penilaian Ahli Materi

\begin{tabular}{|c|l|c|c|}
\hline No & Apek & Persentase & Kriteria \\
\hline 1 & Komponen Kelayakan Isi & $96,25 \%$ & Sangat baik \\
\hline 2 & Komponen Kelayakan Penyajian & $86,25 \%$ & Sangat baik \\
\hline \multicolumn{2}{|c|}{ Rata - rata Skor Total } & $91,25 \%$ & Sangat baik \\
\hline
\end{tabular}

\section{Analisis Data Hasil Evaluasi Ahli Desain Pembelajaran}

Analisis evaluasi ahli desain pembelajaran dilakukan berdasarkan skor rata-rata hasil penilaian ahli desain pembelajaran seperti pada Tabel 8 .

Tabel 8 Skor Rata-rata Hasil Penilaian Ahli Desain Pembelajaran

\begin{tabular}{|c|l|c|}
\hline No & \multicolumn{1}{|c|}{ Kategorisasi } & Persentase Skor \\
\hline 1 & Aspek Pendahuluan & $100 \%$ \\
\hline 2 & Aspek Tujuan ( Hasil Belajar ) & $100 \%$ \\
\hline 3 & Aspek Tes Akhir & $87,5 \%$ \\
\hline 4 & Aspek Pengalaman Belajar & $100 \%$ \\
\hline 5 & Aspek Sumber Belajar & $100 \%$ \\
\hline \multicolumn{2}{|c|}{ Persentase Skor Total } & $\mathbf{9 7 , 6 1 \%}$ \\
\hline
\end{tabular}


Analisis Data Hasil Evaluasi Ahli Media Pembelajaran

Tabel 9. Skor Rata-rata Hasil Penilaian Ahli Media Pembelajaran

\begin{tabular}{|c|l|c|c|}
\hline No. & \multicolumn{1}{|c|}{ Aspek } & Persentase & Kriteria \\
\hline 1 & Desain Kulit Buku ajar & $85,00 \%$ & Sangat baik \\
\hline 2 & Desain Isi Buku ajar & $98,75 \%$ & Sangat baik \\
\hline \multicolumn{2}{|c|}{ Rata - rata Skor Total } & $91,87 \%$ & Sangat baik \\
\hline
\end{tabular}

\section{Analisis Data Hasil Uji Coba Perorangan}

Tabel 10. Persentase Rata-rata Hasil Penilaian Pada Uji Coba Perorangan

\begin{tabular}{|c|l|c|c|}
\hline No & Kategorisasi & Persentase rata-rata & Kriteria \\
\hline 1 & Aspek Kelayakan Isi & $79,16 \%$ & Sangat Baik \\
\hline 2 & Aspek Kelayakan Penyajian & $90 \%$ & Sangat Baik \\
\hline 3 & Aspek Kelayakan Bahasa & $86,11 \%$ & Sangat Baik \\
\hline \multicolumn{2}{|c|}{ Rata - rata } & $\mathbf{8 5 , 0 9 \%}$ & Sangat baik \\
\hline
\end{tabular}

\section{Analisis Uji Coba Kelompok Kecil}

Tabel 11 Persentase Rata-rata Hasil Penilaian Pada Uji Coba Kelompok Kecil

\begin{tabular}{|c|l|l|l|}
\hline No. & \multicolumn{1}{|c|}{ Kategorisasi } & $\begin{array}{c}\text { Persentase } \\
\text { Rata-rata }\end{array}$ & \multicolumn{1}{c|}{ Kriteria } \\
\hline 1 & Aspek Kelayakan Isi & $86,11 \%$ & Sangat Baik \\
\hline 2 & Aspek kelayakan Penyajian & $97,78 \%$ & Sangat Baik \\
\hline 3 & Aspek Kelayakan Bahasa & $92,59 \%$ & Sangat Baik \\
\hline \multicolumn{2}{|c|}{ Rata - rata } & $\mathbf{9 2 , 1 6 \%}$ & Sangat Baik \\
\hline
\end{tabular}

\section{Analisis Data Uji Coba Lapangan}

Tabel 12. Persentase Rata-rata Hasil Penilaian Pada Uji Coba Lapangan

\begin{tabular}{|c|l|l|l|}
\hline No & \multicolumn{1}{|c|}{ Kategorisasi } & $\begin{array}{c}\text { Persentase } \\
\text { Rata-rata }\end{array}$ & \multicolumn{1}{|c|}{ Kriteria } \\
\hline 1 & Aspek Kelayakan Isi & $85,84 \%$ & Sangat Baik \\
\hline 2 & Aspek kelayakan Penyajian & $92,06 \%$ & Sangat Baik \\
\hline 3 & Aspek Kelayakan Bahasa & $85,78 \%$ & Sangat Baik \\
\hline \multicolumn{2}{|c|}{ Rata - rata } & $\mathbf{8 7 , 8 9 \%}$ & Sangat Baik \\
\hline
\end{tabular}

\section{Hasil Penelitian Uji Efektivitas Produk}

Tabel 13. Distribusi Frekuensi Nilai Pretes Peserta didik yang dibelajarkan dengan menggunakan Bahan ajar Desain Grafis Corel Draw Berbasis Kecakapan Hidup (Life Skills) pada lembaga kursus dan pelatihan

\begin{tabular}{|c|c|c|c|c|}
\hline No. Urut & Rentang Nilai & Frekuensi & Persentase & $\begin{array}{c}\text { Persentase } \\
\text { Kumulatif }\end{array}$ \\
\hline 1 & $30-34$ & 2 & 7,7 & 7,7 \\
2 & $35-39$ & 3 & 11,5 & 19,2 \\
3 & $40-44$ & 4 & 19,2 & 38,4 \\
4 & $45-49$ & 9 & 34,6 & 73 \\
5 & $50-54$ & 5 & 19,2 & 92,2 \\
6 & $55-60$ & 2 & 7,7 & 100,0 \\
\hline \multicolumn{2}{|r|}{} \\
\hline
\end{tabular}


Tabel 14. Distribusi Frekuensi Nilai Postes Peserta didik yang Dibelajarkan dengan Menggunakan Bahan ajar Desain Grafis Corel Draw Berbasis Kecakapan Hidup (Life Skills) pada lembaga kursus dan pelatihan

\begin{tabular}{|c|c|c|c|c|}
\hline No. Urut & Rentang Nilai & Frekuensi & Persentase & $\begin{array}{c}\text { Persentase } \\
\text { Kumulatif }\end{array}$ \\
\hline 1 & $65-69$ & 2 & 7,7 & 7,7 \\
2 & $70-74$ & 3 & 11,5 & 19,2 \\
3 & $75-79$ & 11 & 42,3 & 61,5 \\
4 & $80-84$ & 6 & 23,0 & $34,5 \mathrm{saa} 3$ \\
5 & $85-89$ & 3 & 11,5 & 92,2 \\
6 & $90-94$ & 1 & 3,8 & 100,0 \\
\hline \multicolumn{2}{|r|}{ J u m l a h }
\end{tabular}

Tabel 15. Distribusi Frekuensi Nilai Pretes Peserta didik yang Dibelajarkan dengan Menggunakan Buku Ajar Desain Grafis Corel Draw Berbasis Kecakapan Hidup (Life Skills) pada lembaga kursus pelatihan

\begin{tabular}{|c|c|c|c|c|}
\hline No. Urut & Rentang Nilai & Frekuensi & Persentase & $\begin{array}{c}\text { Persentase } \\
\text { Kumulatif }\end{array}$ \\
\hline 1 & $35-39$ & 1 & 3,8 & 7,7 \\
2 & $40-44$ & 4 & 15,4 & 19,2 \\
3 & $45-49$ & 8 & 42,3 & 50 \\
4 & $50-54$ & 8 & 23,0 & 80,8 \\
5 & $55-59$ & 3 & 11,5 & 92,3 \\
6 & $60-64$ & 2 & 3,8 & 100,0 \\
\hline \multicolumn{2}{|r|}{ J u m l a h } & 26 & 100 & \\
\hline
\end{tabular}

Tabel 16. .Distribusi Frekuensi Nilai Postes Peserta didik yang Dibelajarkan dengan Menggunakan Buku Ajar Desain Grafis Corel Draw Berbasis Kecakapan Hidup (Life Skills) pada lembaga kursus pelatihan.

\begin{tabular}{|c|c|c|c|c|}
\hline No. Urut & Rentang Nilai & Frekuensi & Persentase & $\begin{array}{c}\text { Persentase } \\
\text { Kumulatif }\end{array}$ \\
\hline 1 & $55-59$ & 1 & 3,8 & 7,7 \\
2 & $60-64$ & 3 & 11,4 & 19,2 \\
3 & $65-69$ & 9 & 42,3 & 50 \\
4 & $70-74$ & 8 & 23,0 & 80,8 \\
5 & $75-79$ & 3 & 11,5 & 92,3 \\
6 & $80-84$ & 2 & 3,8 & 100,0 \\
\hline \multicolumn{2}{|r|}{ J u m l a h } & 26 & 100 & \\
\hline
\end{tabular}

\section{Uji Persyaratan Analisa Data}

Uji persyaratan analis data dilakukan untuk menentukan uji statistic parametric hipotesis penelitian. Pengujian analisa data dilakukan dengan menguji normalitas dan penelitian dengan uji Chikudrat. Rangkuman uji normalitas data dengan uji Chikudrat adaah sebagai pada Tabel 17.

Tabel 17. Rangkuman Uji Normalitas Data dengan Uji Chikudrat

\begin{tabular}{|c|c|c|c|c|c|}
\hline No. Urut & Data & Kelas & $\mathbf{X}^{\mathbf{2}} \mathbf{h i t u n g}$ & $\mathbf{X}^{\mathbf{2}}$ Tabel & Kesimpulan \\
\hline 1 & Pretes & Eksperimen & 1,169 & 11,070 & Normal \\
\hline 2 & Pretes & Kontrol & 1,030 & 11,070 & Normal \\
\hline 3 & Pretes & Eksperimen & 8,820 & 11,070 & Normal \\
\hline 4 & Pretes & Kontrol & 2,060 & 11,070 & Normal \\
\hline
\end{tabular}

Sedangkan untuk menguji homogenis data penelitian digunakan uji bartlet. Rangkuman uji homogenitas data dengan uji Bartlet sebagai berikut. 
Tabel 18. Rangkuman Uji Homogenitas Data Penelitian

\begin{tabular}{|c|l|c|c|c|}
\hline $\begin{array}{c}\text { No. } \\
\text { Urut }\end{array}$ & \multicolumn{1}{|c|}{ Data } & $\mathbf{X}^{\mathbf{2}} \mathbf{h i t u n g}$ & $\mathbf{X}^{\mathbf{2}}$ Tabel & Kesimpulan \\
\hline 1 & Pretes kelas ekspreimen & 0,143 & 3,841 & Homogen \\
\hline 2 & Pretes kelas control & 0,319 & 3,841 & Homogen \\
\hline 3 & Postes Kelas Eksperimen & \multirow{2}{*nnn}{} \\
\hline 4 & Postes kelas control & 0,19 & \\
\hline
\end{tabular}

\section{Pengujian Hipotesis}

Hipotesis yang diajukan pada penelitian ini adalah terdapat perbedaan yang signifikan antara hasil belajar peserta didik yang dibelajarkan dengan penggunaan bahan ajar dan hasil belajar peserta didik yang dibelajarkan dengan menggunakan Buku Ajar Desain Grafis Corel Draw Berbasis Kecakapan Hidup (Life Skills) pada lembaga kursus pelatihan.

Tabel 19. Rangkuman Perhitungan Uji Hipotesis Data Pretes

\begin{tabular}{|c|c|c|c|c|}
\hline \multicolumn{2}{|c|}{ Rata-rata Nilai Pretes } & $\mathbf{t}_{\text {hitung }}$ & $\mathbf{t}_{\text {Tabel }}$ & Kesimpulan \\
\hline $\begin{array}{l}\text { Menggunakan Bahan } \\
\text { ajar }\end{array}$ & $\begin{array}{l}\text { Menggunakan Buku Ajar Desain } \\
\text { Grafis Corel Draw Berbasis } \\
\text { Kecakapan Hidup (Life Skills) } \\
\text { pada lembaga kursus pelatihan }\end{array}$ & \multirow[t]{2}{*}{$-2,33$} & \multirow[t]{2}{*}{2,0105} & \multirow[t]{2}{*}{$\begin{array}{l}\text { Tidak ada } \\
\text { Perbedaan }\end{array}$} \\
\hline 43,46 & 47,69 & & & \\
\hline
\end{tabular}

Tabel 20. Rangkuman Perhitungan Uji Hipotesis Data Postes

\begin{tabular}{|c|c|c|c|c|}
\hline \multicolumn{2}{|c|}{ Rata-rata Nilai Pretes } & $\mathbf{t}_{\text {hitung }}$ & $\mathbf{t}_{\text {Tabel }}$ & Kesimpulan \\
\hline $\begin{array}{c}\text { Menggunakan Bahan } \\
\text { ajar }\end{array}$ & $\begin{array}{c}\text { Menggunakan Buku Ajar Desain } \\
\text { Grafis Corel Draw Berbasis } \\
\text { Kecakapan Hidup (Life Skills) } \\
\text { pada lembaga kursus pelatihan }\end{array}$ & 7,22 & 2,0105 & $\begin{array}{c}\text { Ada } \\
\text { Perbedaan }\end{array}$ \\
\hline 76,54 & 67,89 & \\
\hline
\end{tabular}

Dari hasil pengujian hipotesis diperoleh bukti empirik bahwa prestasi belajar peserta didik yang menggunakan bahan ajar dalam belajarnya lebih tinggi dibandingkan dengan yang menggunakan Buku Ajar Desain Grafis Corel Draw Berbasis Kecakapan Hidup (Life Skills) pada lembaga kursus pelatihan dengan efektivitas penggunaan bahan ajar sebesar $76,53 \%$. Keefektifan bahan ajar diperoleh dengan cara sebagai berikut :

$$
\begin{array}{ll}
\text { X } & : \frac{\text { Jumlah skoryang diperoleh }}{\text { Jumlah Skor ideal }} \times 100 \% \\
X & : \frac{398}{5201} \times 100 \% \\
X & : 76,53 \%
\end{array}
$$

Nilai keefektifan Buku Ajar Desain Grafis Corel Draw Berbasis Kecakapan Hidup (Life Skills) pada lembaga kursus pelatihan ini lebih tinggi daripada yang tidak menggunakan, yaitu sebesar $67,88 \%$ yang diuraikan sebagai berikut :

$$
\begin{array}{ll}
\mathrm{X} & : \frac{\text { Jumlah skoryang diperoleh }}{\text { Jumlah Skor ideal }} \times 100 \% \\
\mathrm{X} & : \frac{353}{520} \times 100 \% \\
\mathrm{X} & : 67,88 \%
\end{array}
$$

\section{Pembahasan}

Hasil penelitian dari ahli materi terhadap bahan ajar pada materi desain grafis corel draw yang dikembangkan menunjukkan bahwa : (1) komponen bahan ajar dinilai sangat baik dengan persentase rata-rata sebesar 96,25 $\%$ dan (2) komponen substansi materi dinilai sangat baik dengan persentase rata-rata sebesar $86,25 \%$ dengan rata-rata $91,25 \%$. Penilaian ini lebih tinggi daripada penelitian Muhammad Isnaini tentang pengembangan modul pembelajaran fisika berbasis metakognisi yang menunjukkan uji ahli materi berada pada criteria sangat baik (87,5\%), akan tetapi masih lebih rendah dari penelitian Muhammad Jakfar tentang pengembangan buku ajar siswa untuk 
membelajarkan fisika yang berada pada kriteria sangat baik, yaitu sebesar 93,22, serta lebih rendah dari penelitian Arwita tentang Pengembangan Bahan Ajar Biologi Berdasarkan Literasi Sains pada Materi Archaebacteria dan Eubacteria menunjukkan hasil uji ahli materi pelajaran biologi pada penilaian kelayakan isi berada pada kriteria sangat baik (93\%). Dengan demikian bahan ajar desain grafis corel draw pada materi kursus desain grafis corel draw yang dikembangkan secara keseluruhan termasuk dalam kategori sangat baik dan dapat diterima dan layak digunakan dalam proses pembelajaran.

Hasil penilain ahli desain pembelajaran terhadap komponen tampilan fisik dinilai sangat baik dengan persentase rata-rata sebesar 97,61 $\%$. Dengan demikian bahan ajar ini secara keseluruhan termasuk dalam kategori sangat baik sehingga dapat diterima dan layak digunkaan dalam proses pembelajaran. Hasil penilaian ahli media pembelajaran pada kriteria sangat baik dengan persentase rata-rata sebesar 91,87\%. Dengan demikian bahan ajar bahan ajar desain grafis corel draw pada materi desain grafis corel draw yang dikembangkan secara keseluruhan termasuk dalam kategori sangat baik sehingga dapat diterima dan layak digunakan dalam proses pembelajaran.

Dari hasil pengolahan data penelitian yang dilakukan, terdapat perbedaan hasil belajar desain grafis corel draw antara peserta didik yang dibelajarkan dengan menggunakan bahan ajar ini dan peserta didik yang dibelajarkan dengan tidak menggunakan Buku Ajar Desain Grafis Corel Draw Berbasis Kecakapan Hidup (Life Skills) pada lembaga kursus pelatihan yaitu rata-rata hasil belajar desain grafis corel draw peserta didik yang dibelajarkan dengan menggunakan bahan ajar ini lebih tinggi dibandingan dengan peserta didik yang dibelajarkan dengan yang tidak menggunakan Buku Ajar Desain Grafis Corel Draw Berbasis Kecakapan Hidup (Life Skills) pada lembaga kursus pelatihan.

Walaupun dalam penelitian diperoleh data bahwa hasil belajar peserta didik lebih tinggi jika dibelajarkan dengan penggunaan buku ajar ini dari pada hasil belajar yang dibelajarkan dengan tidak menggunakan Buku Ajar Desain Grafis Corel Draw Berbasis Kecakapan Hidup (Life Skills) pada lembaga kursus pelatihan, namun dalam pelaksanaannya Bahan Ajar Desain Grafis Corel Draw Berbasis Kecakapan Hidu (Life Skills) pada lembaga kursus dan pelatihan dan bahan ajar yang lainnya tetap telah mampu meningkatkan pemahaman dan hasil belajar desain grafis corel draw peserta didik. Keefektifan penggunaan bahan ajar adalah sebesar 76,53\% dan Buku Ajar Desain Grafis Corel Draw Berbasis Kecakapan Hidup (Life Skills) pada lembaga kursus pelatihan sebesar $67,88 \%$.

\section{PENUTUP}

Simpulan penilaian tersebut adalah sebagai berikut :

1. Hasil validasi dari ahli materi, ahli desain pembelajaran, ahli media pembelajaran terhadap Buku Ajar Desain Grafis Corel Draw Berbasis Kecakapan Hidup (life skills) pada lembaga kursus dan pelatihan (LKP) yang dikembangkan menunjukkan secara keseluruhan termasuk kategori “ sangat baik "

2. Menurut tanggapan peserta didik pada uji coba perorangan, coba kelompok kecil, uji coba lapangan dinyatakan bahwa buku ajar termasuk kategori "sangat baik"

3. Hasil belajar peserta didik yang dibelajarkan dengan menggunaka bahan ajar ini lebih tinggi dari hasil belajar peserta didik yang dibelajarkan dengan tidak menggunakan Buku Ajar Desain Grafis Corel Draw Berbasis Kecakapan Hidup (Life Skills) pada lembaga kursus pelatihan dengan efektivitas penggunaan bahan ajar sebesar 76,53\% dan efektivitas yang tidak menggunakan Buku Ajar Desain Grafis Corel Draw Berbasis Kecakapan Hidup (Life Skills) pada lembaga kursus pelatihan sebesar $67,88 \%$.

\section{DAFTAR PUSTAKA}

Amri, S. \& Ahmadi, K. (2010). Konstruksi Pembangunan pembelajaran.. Jakarta. Prestasi Pustakarya

Brog, W.R and Gall, M.D. (1983). Education research : An Introduktion. London. Longman, Inc.

Departemen Pendidikan dan Kebudayaan. (1995). Petunjuk Pelaksanaan Proses Belajar Mengajar. Jakarta. Depdikbud

Depdiknas, (2003). Rencana Strategis Pendidikan Nasional. Jakarta. Depdiknas

Imbi, H and Priit, R .(2010). Difficulty of Texts in upper-secondary School Biology Textbook - using Concept Maps for Analysyzing Students New 
Muslich, M.(2010). Texbox Writing; Dasardasar Pemahaman, Penulisan dan Pemakaian Buku Teks. Jogjakarta. Ar Ruzz Media.

Plomp, T. dan Ely, D.P. (1996). International Ecnylopedia of Educational Technology. Ney York. Pergamon

Sanjaya Wina. (2010). Perencanaan dan Desaian Sistem Pembelajaran. Jakarta. Kencana Prenada Media Group.

Sitepu, B.P. (2005). Memilih Buku Pelajaran. Jurnal Pendidikan Penabur. 4(4).

Situmorang,J. (2012). Pengkajian Program Lembaga Kursus dan Pelatihan (LKP) dalam Menyelenggarakan Program Pendidikan Kecakapan Hidup (PKH) di Sumatera Utara, Medan. Jurnal Teknologi Pendidikan Program Pasca Sarjana UNIMED. 5(5).
Sofan dan lif. (2010). Konstruksi Pengembangan Pembelajaran. Jakarta. Prestasi Pustaka

Sumarni,S. 2002, Jurnal Ilmu Pendidikan Islam, Kajian Tentang Konsep, Problem dan Prospek Pendidikan Islam. Yogyakarta. IAIN Sunan Kalijaga, Fakultas Tarbiyah.

Taufiq, Amir. (2009). Inovasi Pendid ikan Melalui Problem Based Learning.Jakarta: Kencana Prenada Media Group.

Thomas, Amstrong. (2002). Sekolah Para Juara. Bandung. Kaifa

Trianto. (2011). Mendesain Model Pembelajaran Inovatif- Progresif. Jakarta. Kencana Prenada Media Group 